【報告】

UDC : $697.11: 697.003 .1: 728.011$

\title{
仙台市の枠組み壁工法による戸建住宅における 温熱・空気環境およびエネルギ消費量の実態調査
}

$\begin{array}{lllll}\text { 正会員 } & \text { 吉 } & \text { 野 } & & \text { 博* } \\ \text { 正会員 } & \text { 長 谷川 } & \text { 房 } & \text { 雄** } \\ \text { 正会員 } & \text { 松 } & \text { 本 } & & \text { 博*** } \\ \text { 正会員 } & \text { 内 } & \text { 海 } & \text { 康 } & \text { 雄**** } \\ \text { 正会員 } & \text { 赤 } & \text { 林 } & \text { 伸 } & \text { 一***** } \\ \text { 正会員 } & \text { 牧 } & \text { 田 } & \text { 一 } & \text { 志****** }\end{array}$

\section{1. 序}

筆者等は従来より東北地方の各種住宅における冬期の 温熱環境の調査を行っている(4)-6)が，今回，仙台市およ びその近郊に建ち，東北地方では断熱気密性能の比較的 高い枠組み壁工法による戸建住宅 13 戸（住宅メーカー 3 社) を対象として, 気密性能, 室内の温熱・空気環境 およびエネルギ消費量の実態調査を行ったので，それら の結果を報告する。

2. 調查概要

\section{1 対象住戸の概要}

住宅の特徴を表一1に，1 階部分の平面図を図一1に 示す。建設時期は, 昭和 56〜59 年である。No. 6 は, 外壁と天井に，それ以外は外壁，床，天井に断熱材が施 されている。断熱材の厚さは, No. 7 が最も厚く, 壁, 天井が $15 \mathrm{~cm}$ ，床が $5 \mathrm{~cm}$ である。B社，C社の住宅の 1 階床はコンクリートスラブで作られており，No.6 以 外の住戸では，床暖房が施され，スラブの下に断熱材が 設置されている。そのうちNo.9, 11, 12, 13 では, 居

表一1 対象住戸の概要

\begin{tabular}{|c|c|c|c|c|c|c|c|c|c|c|c|c|c|}
\hline \multirow{2}{*}{$\begin{array}{l}\text { 住戸 } \\
\text { No. }\end{array}$} & \multirow{2}{*}{$\begin{array}{l}\text { 建設時期 } \\
\text { (人居時期) }\end{array}$} & \multirow{2}{*}{$\begin{array}{l}\text { 延床面䅡 } \\
\text { (䧊数) }\end{array}$} & \multirow{2}{*}{$\begin{array}{ccc}\text { 断 } & \text { 材 } \\
\text { 㕌 } & \text { さ }(\mathrm{cm})\end{array}$} & \multicolumn{6}{|c|}{ 居 間 $\quad(L \cdot L D \cdot L D K)$} & \multirow{2}{*}{$\begin{array}{l}\text { 定室の } \\
\text { 暖房投胫 }\end{array}$} & \multirow{2}{*}{\multicolumn{2}{|c|}{$\begin{array}{ll}\text { 家疾 最高 } & \text { 年問 } \\
\text { 人数 最低 叹人 }\end{array}$}} & \multirow{2}{*}{$\begin{array}{l}\text { 住宅 } \\
x-x-\end{array}$} \\
\hline & & & & 910 広さ & 䞏の潇成 & 休の椣成 & 暖 房 投 碚 & 暖㝰時間 & 暖房䐓間 & & & & \\
\hline 1 & $\begin{array}{l}\text { 昭和 58.1 } \\
\text { 昭和 (59.3) }\end{array}$ & $\begin{array}{l}109.3 \mathrm{~m}^{2} \\
(2)\end{array}$ & 壁 5 ·床 5 •天井7.5 & \begin{tabular}{|l} 
L.DK 14 帖 \\
$\left(23.1 \mathrm{~m}^{2}\right)$
\end{tabular} & $\begin{array}{c}\text { 䘽扈ガラス } \\
\text { 外開き式 }\end{array}$ & じゅうたん & 密門型石油자-ブ & $9.8 \mathrm{hr}$ & 实轿なし & なし & $4 \begin{array}{r}37 \text { 才 } \\
7 \text { 才 }\end{array}$ & $\begin{array}{l}450 \sim \\
500 万 \text { 万 }\end{array}$ & A社 \\
\hline 2 & $\begin{array}{c}58.1 \\
(58.4) \\
\end{array}$ & $\begin{array}{c}104.7 \\
(2)\end{array}$ & 堅5·床 5·天井7.5 & Lox $\begin{array}{c}20 \\
(33.0) \\
\end{array}$ & 二重サッシ & じゅうたん & $\begin{array}{l}\text { 開放型石油朴-ブ } \\
\text { こたつ }\end{array}$ & 8.9 & 4.6 ヶ月 & なし & $\begin{array}{r}34 \text { 才 } \\
5 \text { 才 }\end{array}$ & $\begin{array}{l}500 \sim \\
600 \\
\end{array}$ & A 社 \\
\hline 3 & $\begin{array}{c}58.1 \\
(58.3) \\
\end{array}$ & $\begin{array}{l}108.5 \\
(2) \\
\end{array}$ & 壁5·床5·天井7.5 & $\begin{array}{|cc|}10 & 15 \\
& (24.8) \\
\end{array}$ & 二重サッシ & じゅうたん & 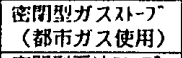 & 6.5 & 4.6 & な し & $5 \begin{array}{l}46 \text { 才 } \\
11 \text { 才 }\end{array}$ & $\begin{array}{l}500 \sim \\
600 \\
\end{array}$ & A 社 \\
\hline 4 & $\begin{array}{c}58.3 \\
(59.10) \\
\end{array}$ & $\begin{array}{c}110.1 \\
(2)\end{array}$ & 壁 5 •床 5 •天井7.5 & Lok $\begin{array}{c}20 \\
(33.0)\end{array}$ & 二重サッシ & じゅうたん & 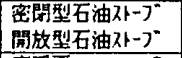 & 8.9 & 4.3 & なし & $\begin{array}{r}54 \\
5 \\
\end{array}$ & $600 \sim$ & A 社 \\
\hline 5 & $\begin{array}{c}59.12 \\
(59.12) \\
\end{array}$ & $\begin{array}{l}108.5 \\
(2)\end{array}$ & 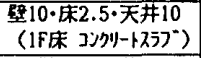 & LOK $\begin{array}{c}18 \\
(29.7)\end{array}$ & 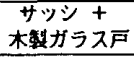 & じゅうたん & 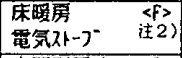 & $\begin{array}{|ll|}\text { 朝方 } & 2 \\
\text { 夕方 } & 1.5 \\
\end{array}$ & 実转なし & 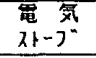 & $\begin{array}{r}37 \text { オ } \\
8 \text { J } \\
\end{array}$ & $\begin{array}{l}350 \sim \\
400\end{array}$ & B 社 \\
\hline 6 & $\begin{array}{l}59.9 \\
(59.9) \\
\end{array}$ & $\begin{array}{c}141.9 \\
(2)\end{array}$ & 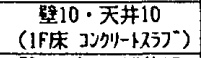 & LOK $\begin{array}{c}29.5 \\
(48.7)\end{array}$ & $\begin{array}{c}\text { サッシ十 } \\
\text { 木整ガラス戸 }\end{array}$ & じゅうたん & 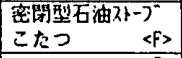 & 9.9 & 4.3 & なし & $\begin{array}{r}545 \text { 出 } \\
11 \text { 才 }\end{array}$ & $600 \sim$ & B社 \\
\hline 7 & $\begin{array}{c}59.9 \\
(59.9) \\
\end{array}$ & $\begin{array}{c}182.6 \\
(2)\end{array}$ & 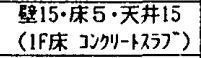 & 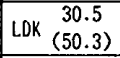 & 二重サッシ & じゅうたん & 床䁔房 & 朝方 2 & 2.0 & なし & $\begin{array}{l}42 \text { 才 } \\
12 \text { 才 }\end{array}$ & $600 \sim$ & B社 \\
\hline 8 & $\begin{array}{c}57.1 \\
(58.2) \\
\end{array}$ & $\begin{array}{c}109.9 \\
(2) \\
\end{array}$ & 壁 5・床 5・天井7.5 & LDK $\begin{array}{c}16 \\
(26.4)\end{array}$ & $\begin{array}{c}\text { 商層カララス } \\
\text { 外開き式 }\end{array}$ & $\begin{array}{l}\text { 板+ } \\
\text { じゅうたん }\end{array}$ & $\begin{array}{l}\text { 密閉型石油사ーブ } \\
\text { こたつ }\end{array}$ & 10.2 & 4.3 & な し & $\begin{array}{r}45 才 \\
0 \\
0\end{array}$ & $\begin{array}{l}350 \sim \\
400 \\
\end{array}$ & A社 \\
\hline 9 & $\begin{array}{c}59.10 \\
(59.10)\end{array}$ & $\begin{array}{c}152.4 \\
(2)\end{array}$ & 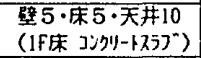 & LOK $\begin{array}{c}19.5 \\
(32.2)\end{array}$ & 二重サッシ & じうたん & 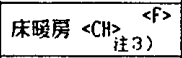 & \begin{tabular}{|l|} 
朝方 2 \\
方 2 \\
\end{tabular} & 実精なし & $\begin{array}{l}\text { 77J1B } \\
\text { こたつ }\end{array}$ & $6 \begin{array}{r}72 \text { 才 } \\
3 \text { 才 }\end{array}$ & $\begin{array}{l}450 \sim \\
500\end{array}$ & C 社 \\
\hline 10 & $\begin{array}{c}58.3 \\
(58.4) \\
\end{array}$ & $\begin{array}{l}147.4 \\
(2)\end{array}$ & 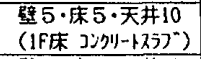 & $L \quad \begin{array}{c}10 \\
(16.5) \\
\end{array}$ & 㭚国ガラス & じゅうたん & 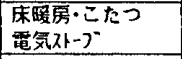 & \begin{tabular}{|ll} 
朝方 & 1 \\
夕方 & 2.5 \\
\end{tabular} & 6.6 & こたつ & $\begin{array}{ll}44 & \text { 才 } \\
& 12 才 \\
\end{array}$ & $600 \sim$ & C社 \\
\hline 11 & $\begin{array}{c}58.8 \\
(58.12) \\
\end{array}$ & $\begin{array}{c}162.7 \\
(2)\end{array}$ & 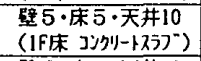 & LoK $\begin{array}{c}25 \\
(41.3)\end{array}$ & 二重サッシ & じゅうたん & 床暖芳〈CH> & \begin{tabular}{|l} 
朝方 2.5 \\
夕方 3 \\
\end{tabular} & 4.0 & 7江仍 & $\begin{array}{r}545 \text { 才 } \\
9 \text { 才 }\end{array}$ & $600 \sim$ & C 社 \\
\hline 12 & $\begin{array}{c}56.6 \\
(56.6) \\
\end{array}$ & $\begin{array}{l}119.5 \\
(2)\end{array}$ & 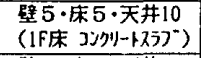 & LDK $\begin{array}{c}22 \\
(36.3)\end{array}$ & 裸绝ガラス & じゅうたん & 床暖房〈CH 〈F〉 & $\begin{array}{l}\text { 朝方 } 2 \\
\text { 夕方 } 2 \\
\end{array}$ & 3.6 & 7\%כ仍 & $\begin{array}{r}35 \\
3 \\
3 \\
\end{array}$ & $600 \sim$ & C社 \\
\hline 13 & $\begin{array}{c}56.8 \\
(56.8) \\
\end{array}$ & $\begin{array}{c}109.0 \\
(1)\end{array}$ & 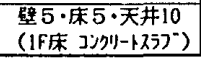 & $\begin{array}{lc}\mathrm{L} & 9 \\
& (14.9) \\
\end{array}$ & $\begin{array}{c}\text { 䄍層カララス } \\
+ \text { + 噇子 } \\
\end{array}$ & じゅうたん & $\begin{array}{l}\text { 床睸房〈CH> } \\
\text { こたつ }\end{array}$ & $\begin{array}{ll}\text { 朝方 } & 0.5 \\
\text { 夕方 } & 1\end{array}$ & 4.0 & 床暖房 & $\begin{array}{l}47 \neq \\
413 \neq \\
\end{array}$ & $\begin{array}{l}500 \sim \\
600 \\
\end{array}$ & C 社 \\
\hline
\end{tabular}

* 東北大学 助教授. 工博

** 東北工業大学 教授. 工博

*** 東北大学 助手. 工博

*****宮城工業高等専門学校 助手・工博

****** 東京大学 助手. 工博

****** 積水化学工業（株），(当時東北大学 大学院生） (昭和 61 年 7 月 10 日原稿受理) 

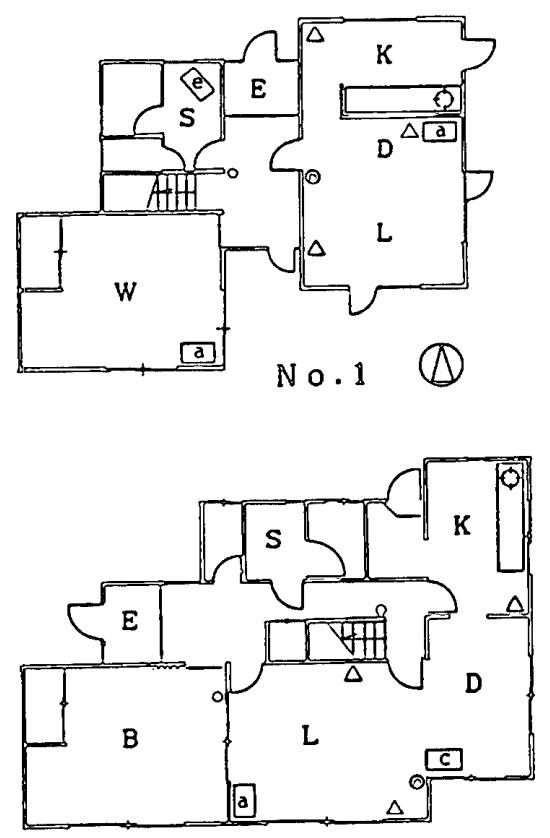

No.4 (1)

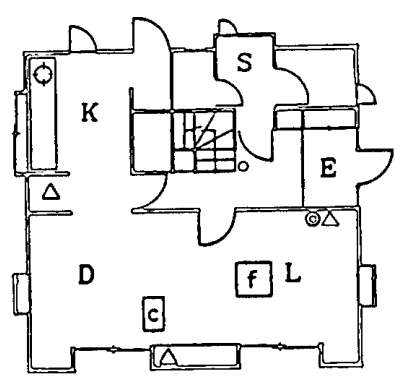

No.2 $ه$

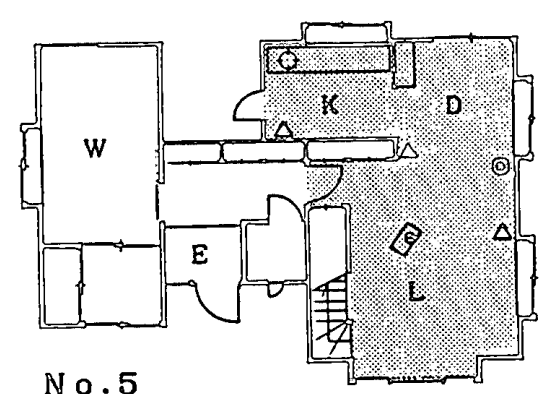

No.5

(底暖房部分約 $30 \mathrm{~m}^{2}$ )

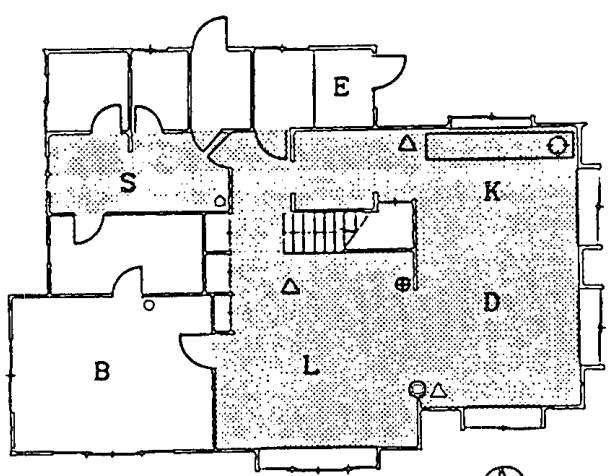

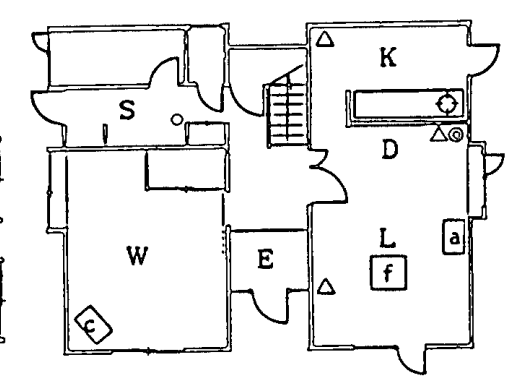

No.8 (D)
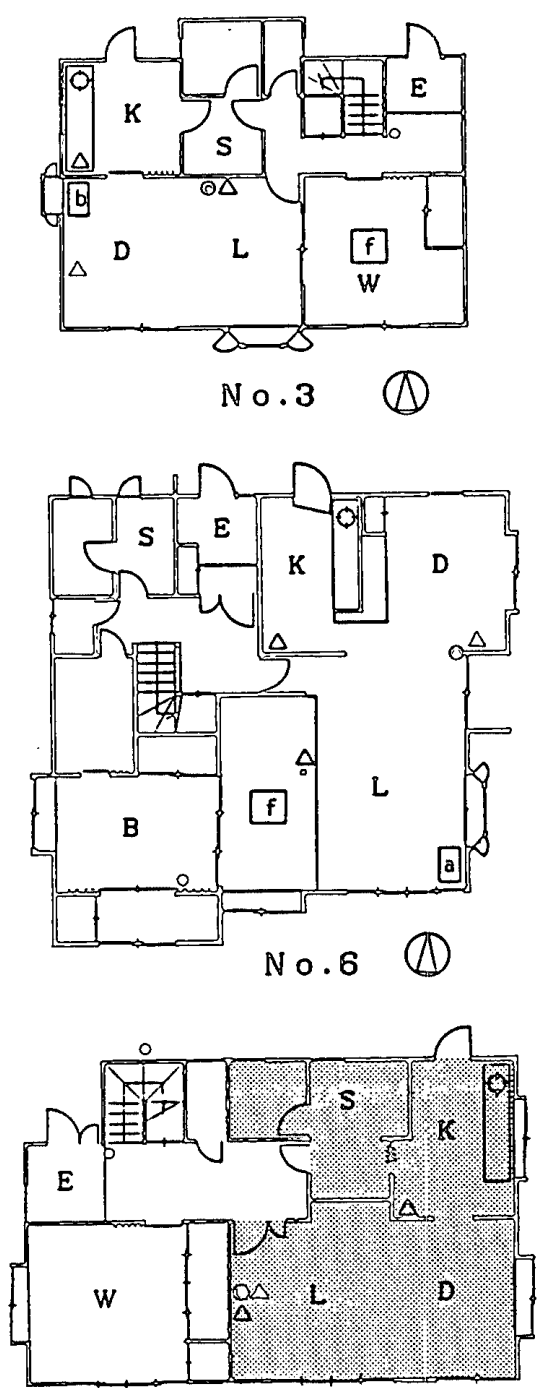

No.9（床暖房部分约 $41 \mathbb{1}^{2}$ )

$\mathrm{No} .7$ (床暖房部分 約 $58 \mathrm{~m}^{2}$ )

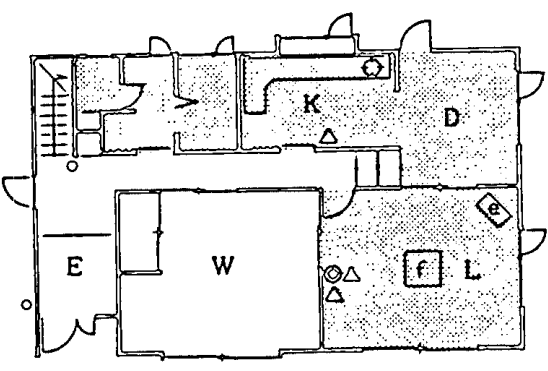

(D)
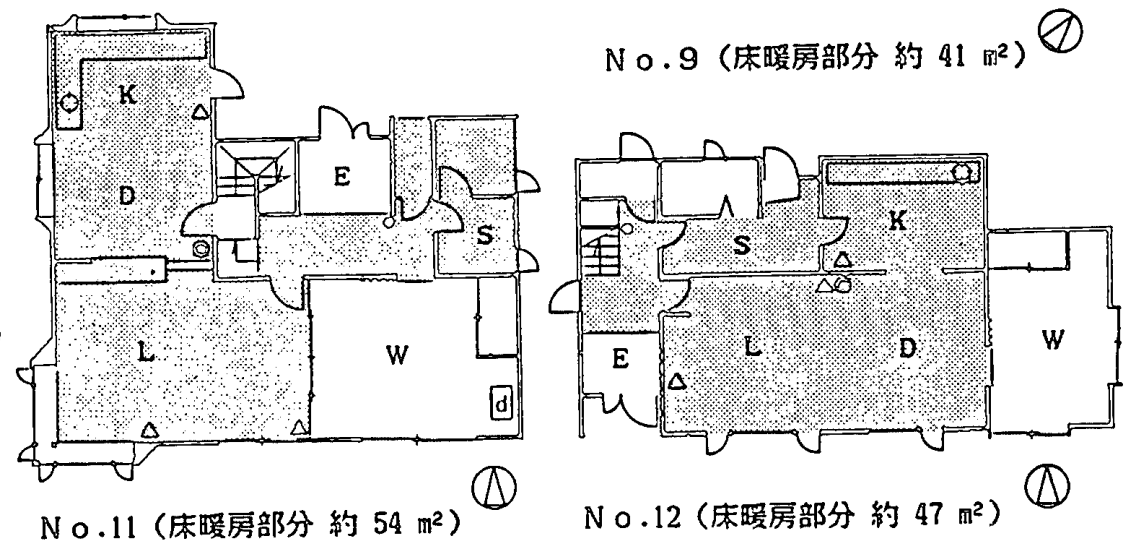

$\mathrm{N} 0.12$ (床暖房部分 約 $47 \mathrm{~m}^{2}$ )

(1)

$\mathrm{N} 0.10$ (床暖房部分 約 $33 \mathrm{~m}^{2}$ )

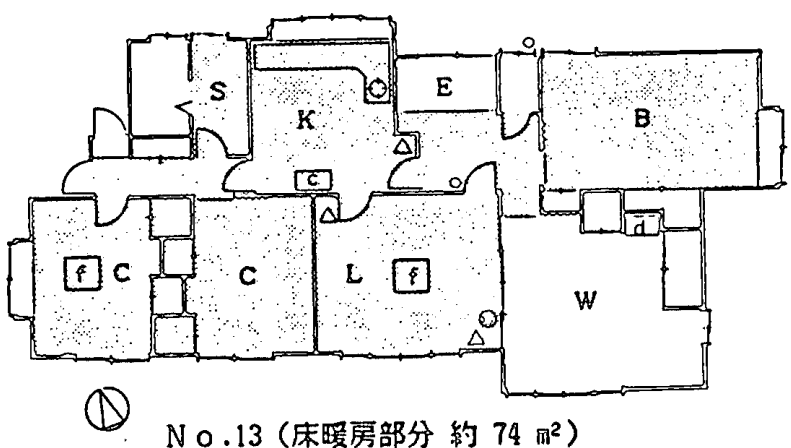

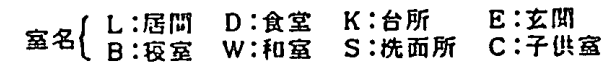

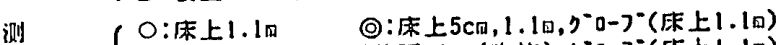

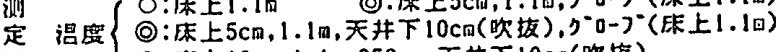
位作

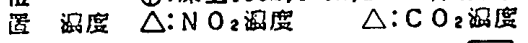

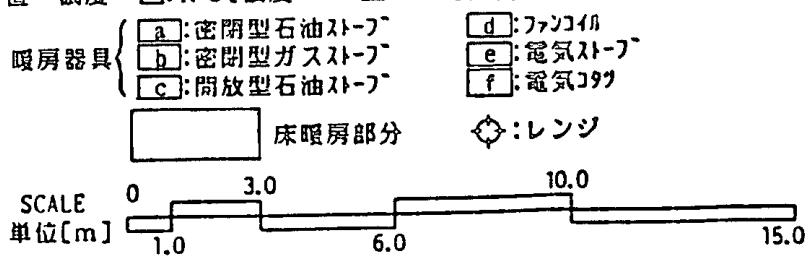

图一1 対象住戸の平面図 (1 階部分) 
表一2 各調查の調查期間

（昭和60年）

\begin{tabular}{|c|c|c|c|}
\hline No. & 気密性能 & 温熱環境 & 空気環境 \\
\hline $\begin{array}{l}1 \\
2 \\
3 \\
4 \\
5 \\
6\end{array}$ & $\begin{array}{l}2 / 8 \\
2 / 8 \\
2 / 8 \\
2 / 12 \\
3 / 2 \\
2 / 1\end{array}$ & \multirow{3}{*}{$\begin{array}{l}1 / 25 \sim 2 / 3 \\
1 / 25 \sim 2 / 3 \\
1 / 25 \sim 2 / 3 \\
1 / 25 \sim 2 / 3 \\
2 / 5 \sim 2 / 12 \\
1 / 26 \sim 2 / 3 \\
1 / 26 \sim 2 / 3 \\
2 / 5 \sim 2 / 12 \\
2 / 6 \sim 2 / 12 \\
2 / 6 \sim 2 / 12 \\
2 / 6 \sim 2 / 12 \\
2 / 6 \sim 2 / 12 \\
2 / 6 \sim 2 / 12 \\
2 / 6 \sim 2 / 12\end{array}$} & $\begin{array}{c}2 / 1 \sim 2 / 2 \\
2 / 28 \sim 3 / 2 \\
1 / 29 \sim 1 / 30 \\
1 / 30 \sim 1 / 31 \\
1 / 31 \sim 2 / 1 \\
2 / 2 \sim 2 / 3\end{array}$ \\
\hline 7 & $3 / 2$ & & $2 / 4 \sim 2 / 5$ \\
\hline $\begin{array}{l}8 \\
9 \\
10 \\
11 \\
12 \\
13\end{array}$ & $\begin{array}{l}3 / 8 \\
1 / 31 \\
3 / 8 \\
\cdots \cdots \\
3 / 13 \\
3 / 13\end{array}$ & & $\begin{array}{c}2 / 6 \sim 2 / 7 \\
2 / 7 \sim 2 / 8 \\
2 / 7 \sim 2 / 8 \\
2 / 8 \sim 2 / 9 \\
2 / 9 \sim 2 / 10 \\
2 / 13 \sim 2 / 14\end{array}$ \\
\hline
\end{tabular}

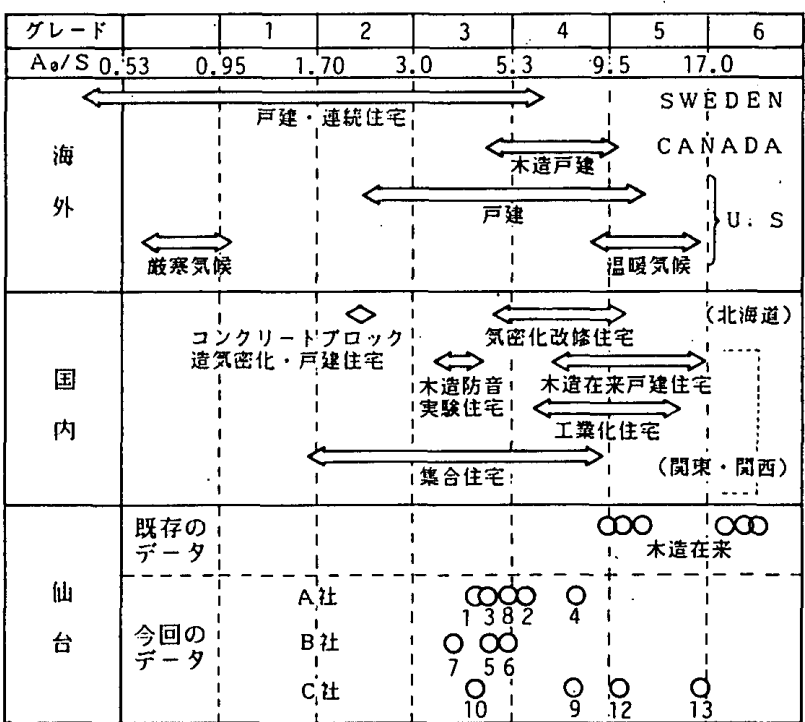

図一4 気密性能についての既往データとの比較

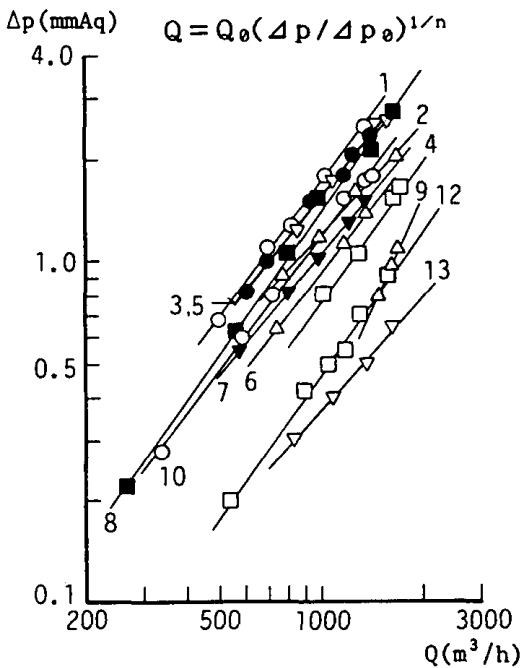

図-2 気密性能の測定結果

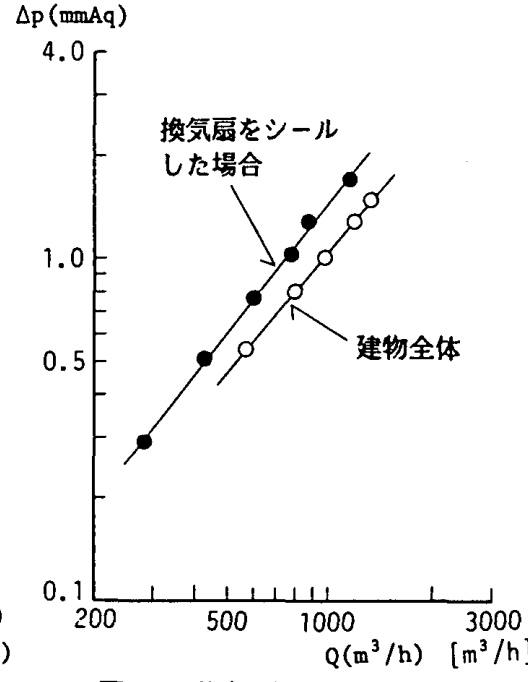

図一3換気扇まわりの腙間の 測定結果 (No.7)

\begin{tabular}{r|r|r|r|l}
\multicolumn{5}{c}{ 表一3 3 各住戸の気密性能 } \\
\hline No. & $Q_{\ominus}$ & $\mathrm{A}_{\odot}$ & $\mathrm{A}_{\odot} / \mathrm{S}$ & $\mathrm{n}$ \\
\hline 1 & 672 & 463 & 4.24 & 1.29 \\
2 & 845 & 598 & 5.70 & 1.07 \\
3 & 706 & 500 & 4.61 & 1.24 \\
4 & 1200 & 851 & 7.73 & 1.37 \\
5 & 706 & 500 & 4.61 & 1.22 \\
6 & 1060 & 748 & 5.27 & 1.28 \\
7 & 973 & 688 & 3.77 & 1.18 \\
8 & 792 & 560 & 5.10 & 1.39 \\
9 & 1630 & 1150 & 7.57 & 2.19 \\
10 & 882 & 624 & 4.23 & 1.30 \\
11 & $\ldots \ldots .$. & $\ldots \ldots$. & $\ldots \ldots .$. & $\ldots \ldots$. \\
12 & 1720 & 1210 & 10.17 & 1.40 \\
13 & 2470 & 1750 & 16.08 & 1.11 \\
\hline
\end{tabular}

壾号

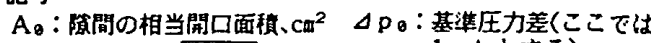
$A_{\theta}=2.78 \sqrt{r_{\mathrm{R}} / 2 \mathrm{~g}} Q_{\theta}$ $Q$ : 流量、 $a^{3} / \mathrm{h}$ 1 mmAqとする)

$\mathrm{Q}_{\mathrm{\theta}}: \Delta \mathrm{p}=\Delta \mathrm{p}_{\theta}$ の場合の : 流量、賍力表、 $\mathrm{n}$ : 柗閣の特性檤

間以外の部屋にもファンコイルが設置され，セントラル $r_{\mathrm{R}}$ : 外気比重量、 $\mathrm{kg} / \mathrm{m}^{3}$ $8:$ 重力加速度、 $\mathrm{m} / \mathrm{s}^{2}$ $\mathrm{S}:$ 延床面積、 $\mathbb{m}^{2}$ また, ストーブ使用の住戸のうち, No. 2 とNo. 4 の食 堂では開放型然焼暖房器具を使用しており, 他は密閉型 燃焼暖房器具を使用している。居間の空は複層ガラス, または二重空である。No.1 と No. 8 は複層ガラスで外 開き式である。また，すべての住戸において断熱材の内 側にポリエチレンの防湿シートが施されている。

\section{2 調查内容}

\section{（1）気密性能}

建物全体の気密性能の測定は，No.11を除く 12 戸を 対象として，加圧法により行った。ただしNo.7につい ては台所の換気扇, 熱交換型換気扇 3 台, 浴室および便 所の換気扇の合計 6 台を対象にした場合についても測定 した。

\section{（2）温熱環境}

各住戸において居間を中心として, 約 10 日間にわた

り室温の連続測定を行った。

\section{(3) 空気環境}

各住戸の居間の $\mathrm{CO}_{2}$ 濃度と居間, 台所の $\mathrm{NO}_{2}$ 濃度に ついて 1ー3 日間の测定を行った。

\section{（4）エネルギ消費量}

各住戸の電気, ガス, 灯油の 1 年間の消費量を調查し 集計した。

\section{3 調查時期}

謂査期間は，エネルギ消費量調査を除いて，昭和 60 年 1 月 25 日から 3 月 13 日までである。各住戸について の気密性能, 温熱環境および空気環境の調查期間を表一 2 に示す。エネルギ消費量調查については後述する。

\section{3. 対象住戸の気密性能}




\section{1 测定方法}

空に発泡スチレンをはめ込み，そこにダクトを貫通さ せ，室内側のダクト先端にファンを設置して室内全体を 加圧した。外周の開口部は閉じ，内部の間仕切りはすべ て開放した。開口部，換気扇等には特に目ばりは施して いない。圧力は精密微差圧変換器により测定し，風黾は ダクトの中心風速を熱線風速計で測定し，盺面積と補正 係数を挂けて推定した。測定範囲は $\Delta p=0.2 \sim 3.0$ $\mathrm{mmAq}$ であるが, 建物の隙間が大きい場合には, 0.2 $0.7 \mathrm{mmAq}$ であった。

\section{2 建物全体の気密性能}

図一2に測定結果を示す。測定值から最小自乗法で回 䚻直線を求め， $Q_{0}$ と $n$ を算出すると表一 3 のようにな る。No. 9 の測定時は風が少し強く, $\Delta p=0.9 \mathrm{mmAq}$ 以 下での測定ができなかったので，十分な精度が得られて いない。そのため $n$ の值は 2.0 を越えている。No. 9 を 除くと $n$ の值は 1.07 1.40である。Q $Q_{0}$ より $A_{0}, A_{0} / S$ （単位床面積当たりの相当開口面積）を算出すると表一
3 のようになる。 $A_{0} / S$ は 3.77〜16.1 の間でばらついて いる。

3.3 換気扇まわりの隙間について

図一3にNo.7 の測定結果を示す。合計 6 台の換気扇 をシールした場合とはがした場合との測定結果により， $A_{0}$ を求めると $151 \mathrm{~cm}^{2}$ となる。これは隙間全体の $22 \%$ であり，大きな割合を占める。また，換気扇一台当たり では $25 \mathrm{~cm}^{2}$ の隙間があることになる。

\section{4 既往データとの比較}

気密性能を $A_{0} / S$ の值で既往データ71,8) と比較して図 -4に示す。今回測定した住戸は $3 \sim 5$ のグレード过1に 入り，前回测定した仙台の住宅 ${ }^{9)}$ に比べて，No.12,13 を除き気密である。A社のうちNo.1の住戸が最も気密 である。No.2, 3, 4 は二重空で引き違い式である。No. 8 は，座數以外は外開き式であるが，気密性能はNo. 1 ほど高くはない。B社はA社に比べるとばらつきは少な く, 3 社の中では全体に気密である。No.5，6，7では， 居間にも換気扇（熱交換型）を設置しているが，入居者

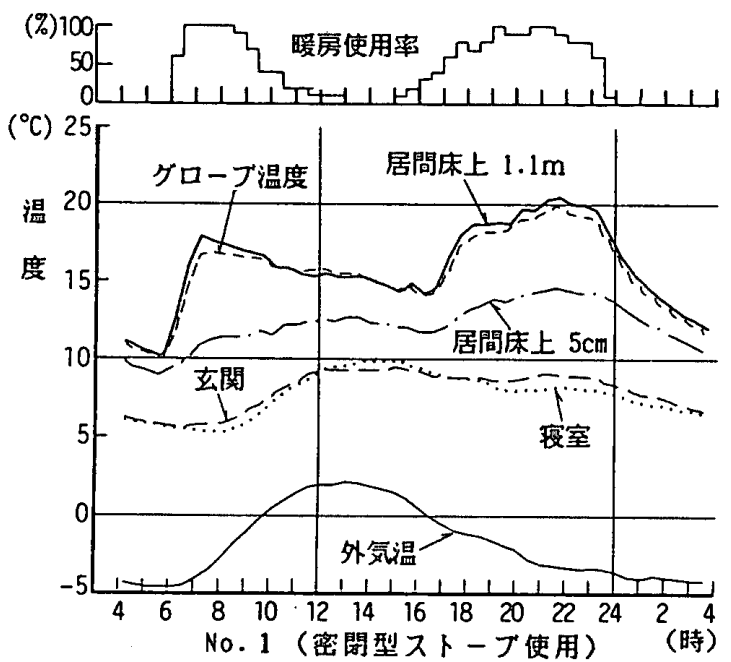

四床暖房の遭䎐時間

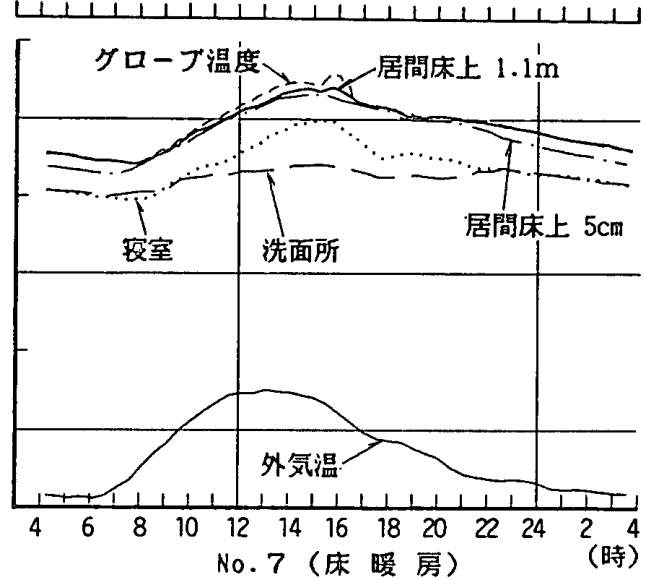

图一5 室温の平均日変化の例
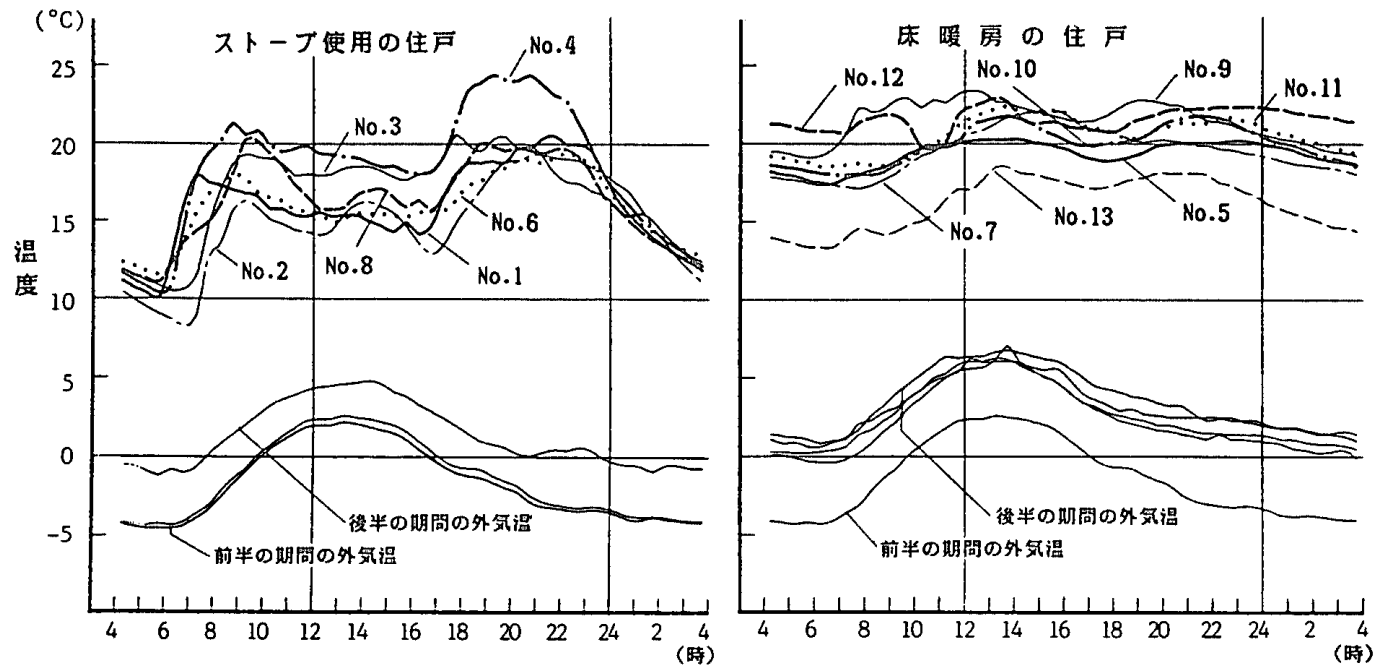

图一6 全住戸の居間床上 $1.1 \mathrm{~m}$ の温度の平均日変化 

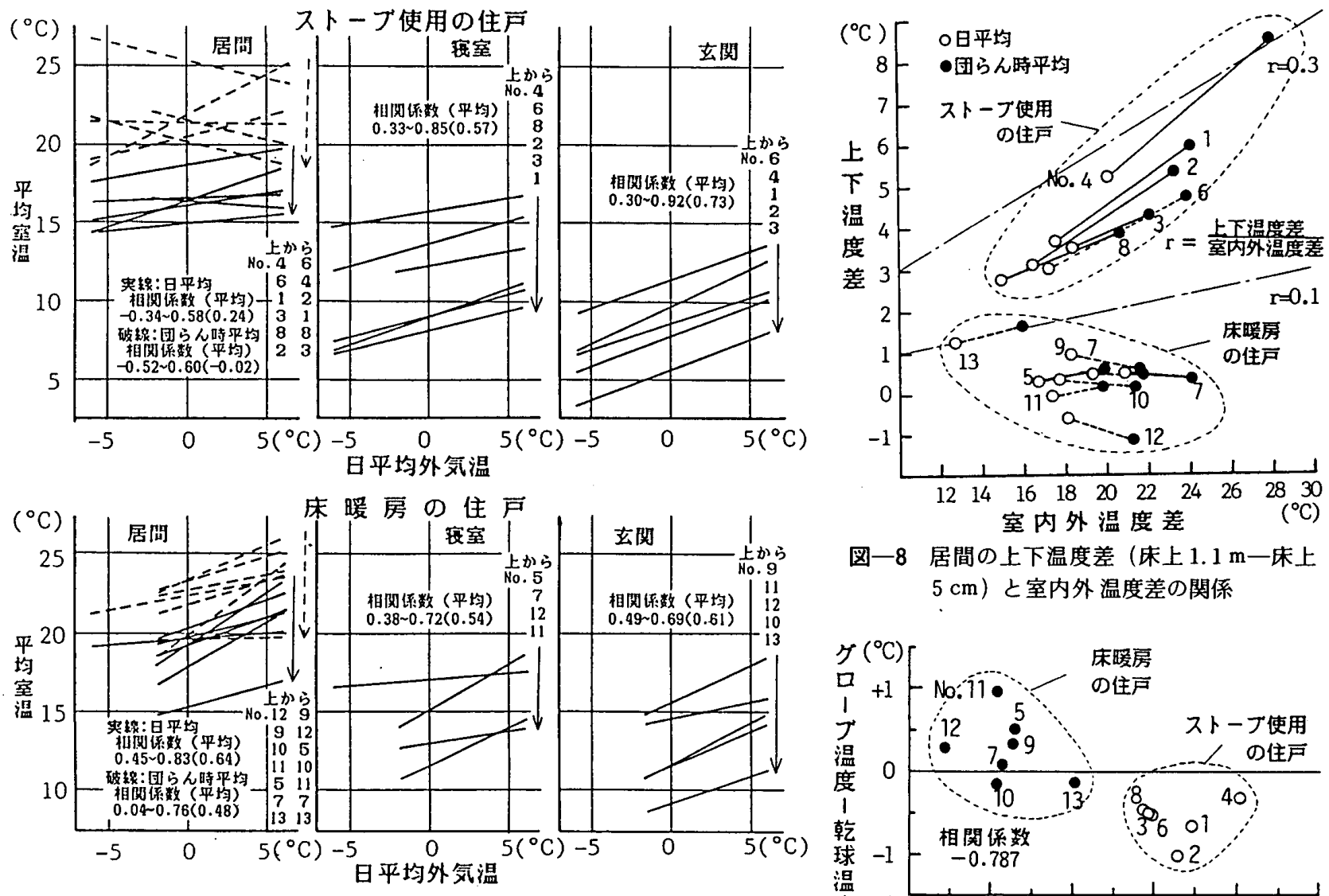

图一7日平均外気温に対する室温の回帰直線

図一8 居間の上下温度差（床上 $1.1 \mathrm{~m}$ 一床上 $5 \mathrm{~cm})$ と室内外温度差の関係

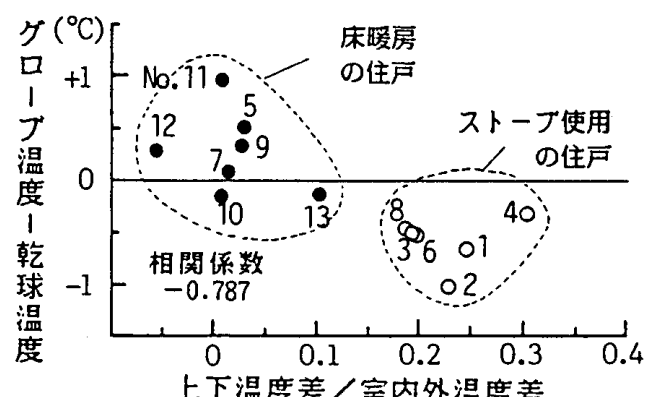

図一9 居間のグローブ温度と上下温度差の関係

(団らん時)

の話によると風の強い時には運転停止時にその部分から の隙間風を感じるとのことであり，それらの換気扇には 隙間がかなりあるものと推定される。C社の場合最もば らつきが大きく, No.12,13 の住宅の気密性は従来の住 宅と変わらない。No. 12 は合成樹脂性の気密サッシを 使用しているが，居間にも換気扇（熱交換型）を2台設 置しているので，隙間が多いものと推定される。

\section{4. 温熱環境調査}

\section{1 調查方法}

測温抵抗体を用いて，約 10 日間の温度の連続測定を 行った。測定箇所は, 1 戸当たり 6 点 (居間の床上 $1.1 \mathrm{~m}$, 林上 $5 \mathrm{~cm}$, 寝室, 玄関の床上 $1.1 \mathrm{~m}$ の乾球温度, 居間 のグローブ温度，外気温など）である。図一1に測定位 置, 暖房器具の配置を示す。No. 7 は測定点を換えて 2 回測定している。データは 30 分ごとに平均し, 夕食後 の室温の安定している時間帯を“団らん時”とした。

\section{2 調查結果}

\section{(1) 外気温}

調查期間中の外気温の平均値は, 前半の期間 (1/25 $2 / 3)$ が約 $-1.6^{\circ} \mathrm{C}$, 後半の期間 $(2 / 5-2 / 12)$ は約 $2.3^{\circ} \mathrm{C}$ であった。

\section{（2）室温の平均日変化}

図一5に，密閉型ストーブ使用の住戸(No.1) と床 暖房使用の住戸 (No.7) の結果を示す。No.1 では居間

の温度は暖房使用率 ${ }^{22}$ の変化に伴い上下する。床上 1.1

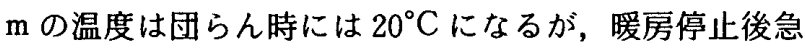
激に下降し，明け方には $10^{\circ} \mathrm{C}$ とる。床上 $5 \mathrm{~cm}$ との 温度差は最高 $6^{\circ} \mathrm{C}$ である。グローブ温度は乾球温度よ りも暖房時に最大約 $1^{\circ} \mathrm{C}$ 低い。玄関, 寝室の温度は変 化が少なく $5^{\circ} \mathrm{C}$ - $10^{\circ} \mathrm{C}$ の範囲にある。一方, No. 7 では 温度の変化は少ない。休暖房の運転は朝 7 時〜 9 時の 2 時間のみであるが, 居間の床上 $1.1 \mathrm{~m}$ の温度は一日中 $17^{\circ} \mathrm{C}$ - $22^{\circ} \mathrm{C}$ である。また，上下温度差は極めて小さく， 床面からのふく射の効果によりグローブ温度は乾球温度 と等しいかやや高い。寝室, 洗面所の温度は $15^{\circ} \mathrm{C}$ $20^{\circ} \mathrm{C}$ である。

全住戸の居間床上 $1.1 \mathrm{~m}$ の温度をストーブ暖房と床 暖房の住戸に分けて図一6に示す。それぞれ，図一 5 と 同様の変化を示すが, No. 4 は団らん時にやや高く, No.13 はやや低い。

\section{（3）日平均外気温と室温の関係}

両者の関係から求めた回帰直線を図一7に示す。相関 係数の值は大幅に異なるが，おおよそ居間，寝室，玄関 の順に高くなる。外気温が $0^{\circ} \mathrm{C}$ の時の室温は, スト一 ブ暖房, 床暖房のそれぞれについて, 居間日平均 $16.5^{\circ} \mathrm{C}$, $19.0^{\circ} \mathrm{C}$, 団らん時 $21.9^{\circ} \mathrm{C}, 21.9^{\circ} \mathrm{C}$, 寝室 $11.3^{\circ} \mathrm{C}, 14.2^{\circ} \mathrm{C}$, 


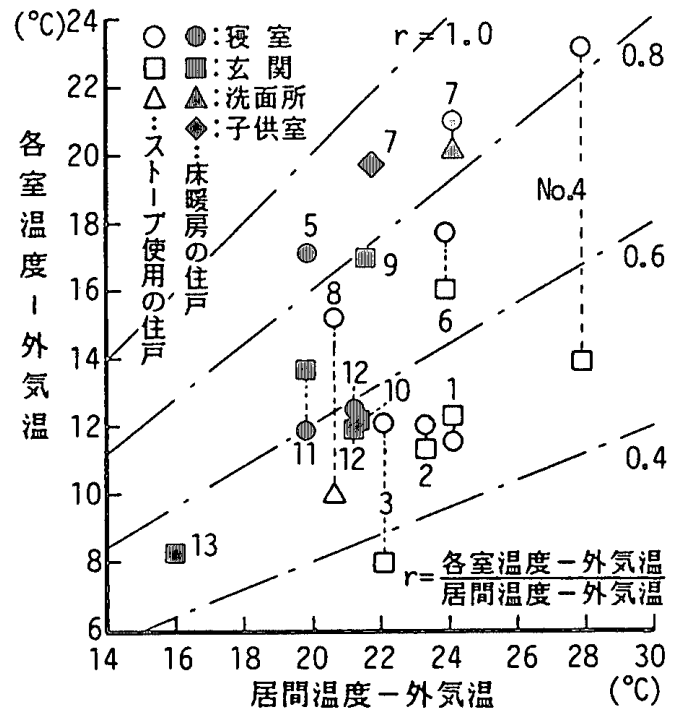

图一10 居間と他の部屋の温度の関係（団らん時）

玄関 $8.6^{\circ} \mathrm{C}, 12.6^{\circ} \mathrm{C}$ である。仙台の公社分䛊住宅を対

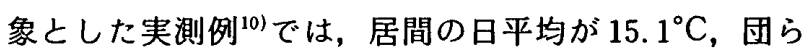
ん時 $22.0^{\circ} \mathrm{C}$, 寝室 $8.0^{\circ} \mathrm{C}$, 廊下 $6.2^{\circ} \mathrm{C}$ であり, 居間の 団らん時を除いて今回の方が温度は高い。特に, 床暖房 の住宅の寝室, 玄関で高い。

(4) 居間の上下温度差

室内外温度差との関係を図一 8 に示す。床暖房の住戸 はいずれも温度差が極めて小さい。床暖房住戸の断熱・ 気密性能が他に比べて特に磁れているということはない ので，温度差が小さいことの主な原因は床暖房のためで あると推定される。No. 12 では床上 $5 \mathrm{~cm}$ の方が逆に高 い。No.5, 7 は居間に吹き抜けがあるが団らん時の温度 は, No. 5 では床上 $5 \mathrm{~cm}$ が $21.2^{\circ} \mathrm{C}, 1.1 \mathrm{~m}$ が $21.8^{\circ} \mathrm{C}$, 吹き抜け天井下 $10 \mathrm{~cm} \mathrm{が} 21.9^{\circ} \mathrm{C}$, No.7では, 林上 10 $\mathrm{cm}$ が $22.1^{\circ} \mathrm{C}, 1.1 \mathrm{~m}$ が $22.6^{\circ} \mathrm{C}$, 吹き抜け天井下 $10 \mathrm{~cm}$ が $22.1^{\circ} \mathrm{C}$ であり, 極めて温度差が小さい。これは床暖 房のためだけでなく，断熱気密性能が大変高いことにも 起因するものと推察される。ストーブ暖房の住宅では, 上下温度差と内外温度差の比が $0.1 \sim 0.3$ であり, 前回 の実測(列10)では $0.3 \sim 0.5$ であったのに比べて小さい。

（5）グローブ温度

グローブ温度を上下温度差との関係で見るために, 団 らん時のグローブ温度と乾球温度の差と, 上下温度差を 内外温度差で基準化した値との関係を図一 9 に示す。全 体に負の相関が見られる。床暖房の住戸は，床面からの ふく射の効果によりグローブ温度は乾球温度よりも最大 $1^{\circ} \mathrm{C}$ 高い。

（6）居間と他の部屋の温度

団らん時の外気温基準の居間温度と他の部屋の温度之 の関係を図一10 に示す。No. 3 の玄関を除き, 両者の比 は $0.5 \sim 0.9$ であり，前回の実測例 ${ }^{10)}$ では $0.3 \sim 0.8$ で あったのに比べて，やや大きい。アンケート調査によれ
ば,居間と台所の温度に対してはほとんどの住戸で“ちょ うど良い”と答え, 寝室, 玄関では約半数が “やや寒い” と答えている。

\section{5. 空気罢㜔調盗}

5.1 調㚗方法

$\mathrm{CO}_{2}$ 浱度は, 赤外線 $\mathrm{CO}_{2}$ 分析計 2 台を用いて, 持ち 回りで居間のみについて1〜2 日間測定した。なおデー 夕は 30 分ごとに読み取っている。 $\mathrm{NO}_{2}$ 濃度は, バッジ 型 $\mathrm{NO}_{2}$ 測定器新 を居間と台所で 3 日間暴露し, 日平均 の $\mathrm{NO}_{2}$ 灙度を求めた。濃度測定位置を図一 1 に示す。 なお, 気象台の風速データと室内外温度差の実測值によ れば，搌度測定時における風力および温度差による室内 外圧力差には，住戸間で大きな差はないと推定された。

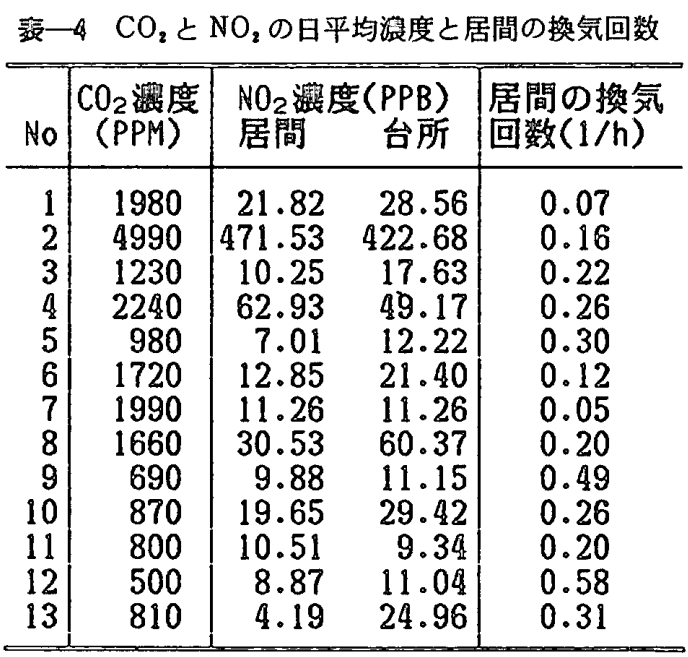

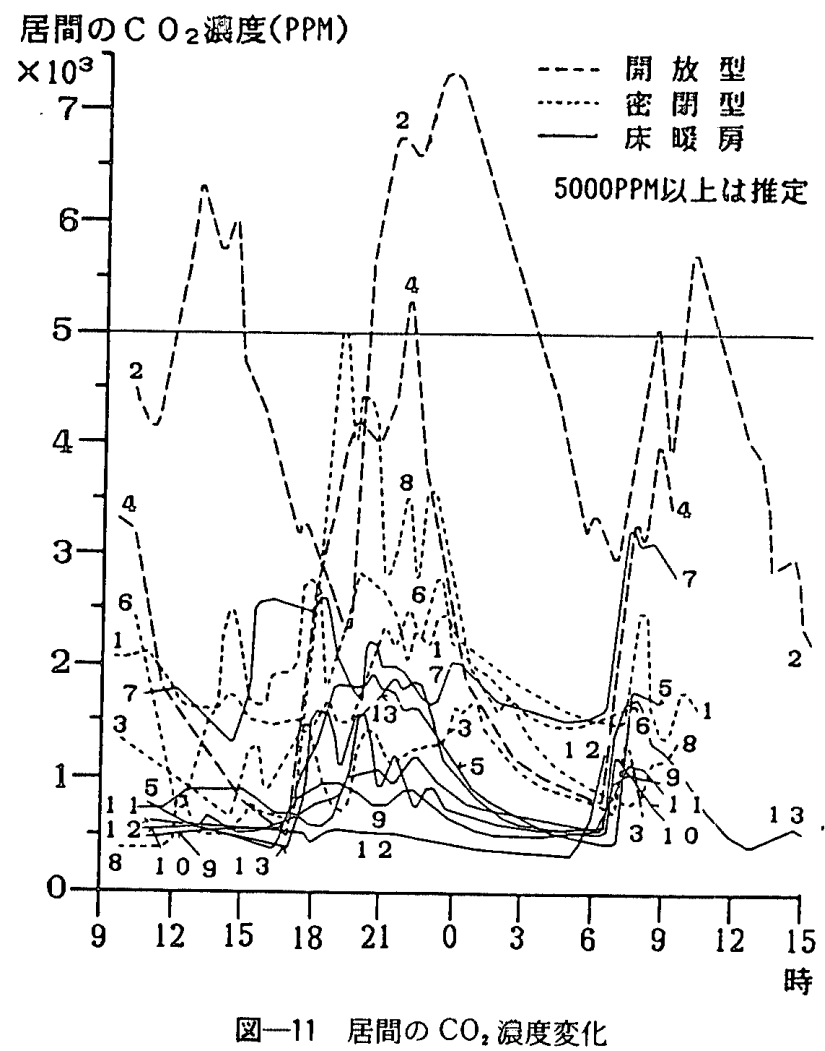




\section{$5.2 \mathrm{CO}_{2}$ 濃度の測定結果}

(1) 時間変化

異なる日に測定した各住戸の $\mathrm{CO}_{2}$ 濃度を時刻を揃え て図一11に示す。また日平均濃度を表一 4 に示す。(た だし測定範囲（0〜5000 ppm）を越えて出力された場合 には，測定範囲の特性曲線を 3 次式により外挿して推定 した。）21 時には $500 \mathrm{ppm} ７ 000 \mathrm{ppm}$ の值を示すなど 各住戸によるばらつきが大きいが，全体に朝と夜に濃度 が高くなる傾向が見られ，これは炊事と人体による影響 と考えられる。なお温風式開放型ストーブ(いわゆるファ ンヒーター) 使用の No.2の住戸は著しく高い。

(2) 累積度数

各住戸の $\mathrm{CO}_{2}$ 濃度の一日分を取り出し，その相対累

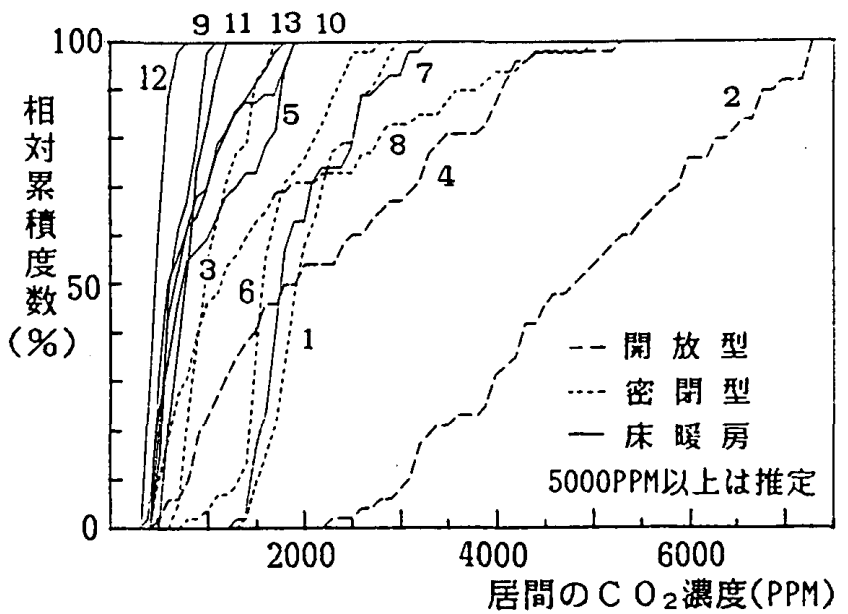

图一12 居間の $\mathrm{CO} 2$ 濃度の相対累積度数
積度数を図一12に示す。ただし一日に満たないデー夕 が一部ある。No.1，2，4，6，7 の住戸は $\mathrm{CO}_{2}$ 濃度が $1000 \mathrm{ppm}$ を越える時間が 1 日の 7 割以上を占める。さ らに終日 $1000 \mathrm{ppm}$ を越える住戸が 3 戸（No. 1，2，7） 見られ，特にNo. 2 は終日 $2000 \mathrm{ppm}$ 以上である。いず れの住戸も居間と台所の間が開放されているが, No.2, 4 では開放型ストーブを用いている。No.1，7 は今回の 実測例の中で最も気密性能が高い。床暖房の住戸は No.7を除いて相対的に濃度が低い。

\section{$5.3 \mathrm{NO}_{2}$ 濃度の測定結果}

居間と台所の日平均 $\mathrm{NO}_{2}$ 濃度を表一 4 に示す。No. 2

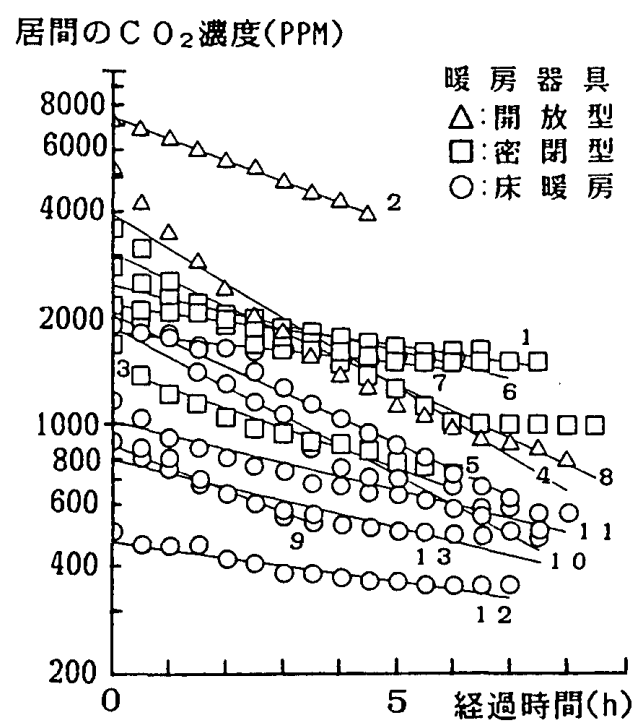

图一16 居間の $\mathrm{CO}_{2}$ 濃度诚衰

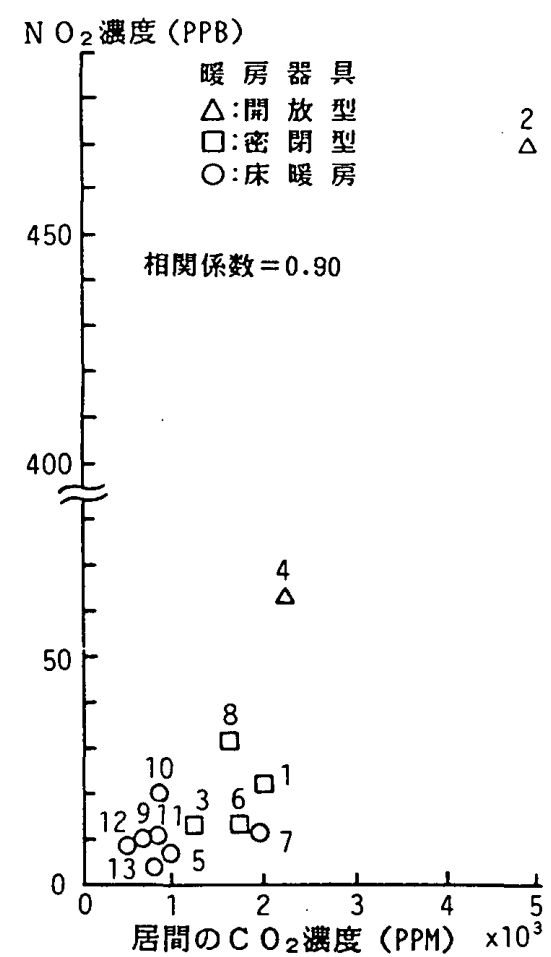

图一13 居間の日平均 $\mathrm{CO}_{2}$ 濃度之 $\mathrm{NO}_{3}$ 濃度の関係

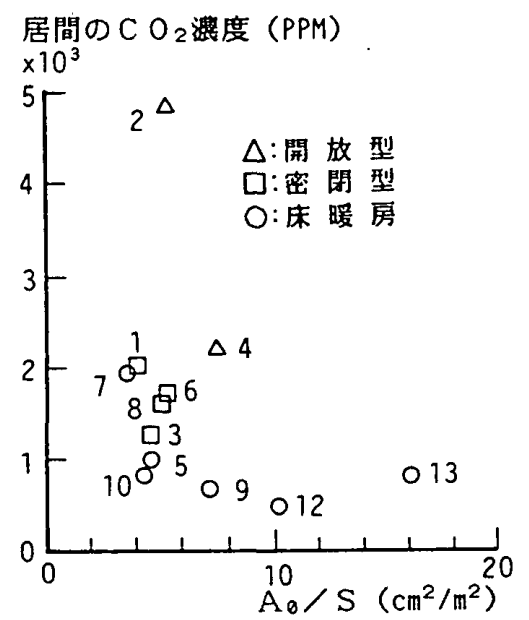

图一14 気密性能 $\left(A_{0} / S\right)$ と居間の 日平均 $\mathrm{CO}_{2}$ 濃度

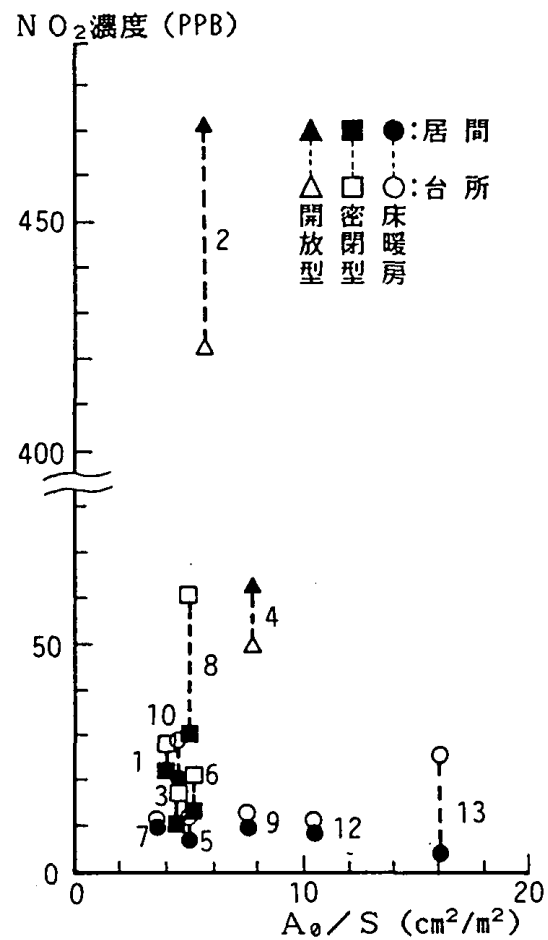

図一15 気密性能 $\left(A_{0} / S\right)$ 之居間, 台所の 日平均 $\mathrm{NO}_{2}$ 濃度 
の住戸の $\mathrm{NO}_{2}$ 灙度が極端に高く, No. 4 が次に高い。図 -13 に $\mathrm{CO}_{2}$ 灙度と $\mathrm{NO}_{2}$ 灙度の関係を示す。両者に正の 相関が見られ，開放型ストーブを使用する住戸で $\mathrm{NO}_{2}$ 泿度も高灙度になっている。またNo. 2,4, 11 を除き台 所の濃度が居間より高いが, 炊事による影響と考えられ る。No. 2 は居間で開放型ストーブを用いているため, No. 4 は居間と台所の間が開放されており，かつ設置し たバッジと開放型ストーブとの距離が比較的近いために 逆䎐したものと考えられる。

\section{4 気密性能と室内空気污染漂度}

（1）気密性能と $\mathrm{CO}_{2}$ 湱度

日平均 $\mathrm{CO}_{2}$ 曟度と $A_{0} / S$ (単位床面積当たりの相当開 口面積）との関係を図一14 に示す。 $A_{0} / S$ が小さいほど $\mathrm{CO}_{2}$ 濃度の高い住戸が増加する傾向があり $6 \mathrm{~cm}^{2} / \mathrm{m}^{2}$ 以 下の場合には，8例中 6 例が $1000 \mathrm{ppm}$ を越えている。

(2) 気密性能と $\mathrm{NO}_{2}$ 濃度

日平均 $\mathrm{NO}_{2}$ 濃度と $A_{0} / S$ の関係を図一 15 に示す。 $\mathrm{CO}_{2}$ 濃度と同様に $A_{0} / S$ が小さいほど濃度の高い住戸が 増加する傾向がある。

\section{5 居間の換気回数の推定}

(1) 推定方法

深夜から早朝の間の $\mathrm{CO}_{2}$ 濃度を, 時刻を揃えて図一 16 に示す。室内外温度差が早朝にかけて減少するため に，濃度減衰が直線にならない住戸が大部分である。こ の間の $\mathrm{CO}_{2}$ 発生は居間においてはほとんど無いと考え られるので, 試みに 30 分間は外部風速, 室内外温度差 が一定と仮定して居間の換気回数を 30 分ごとに求め, 全体で平均した結果を表一4に示す。

\section{（2）気密性能之換気回数}

$A_{0} / S$ と換気回数の関係を図一 17 に示す。両者には正 の相関が見られるが $A_{0} / S$ は建物全体を対象とした值で あり，換気回数は居間のみによる値を基に算定している ことに注意する必要がある。No. 9, 12, 13 の換気回数 の大きい住戸は，隙間も大きく，表一4によれば日平均 の $\mathrm{CO}_{2}$ 濃度が低いことが分かる。

\section{6. エネルギ消贸通調查}

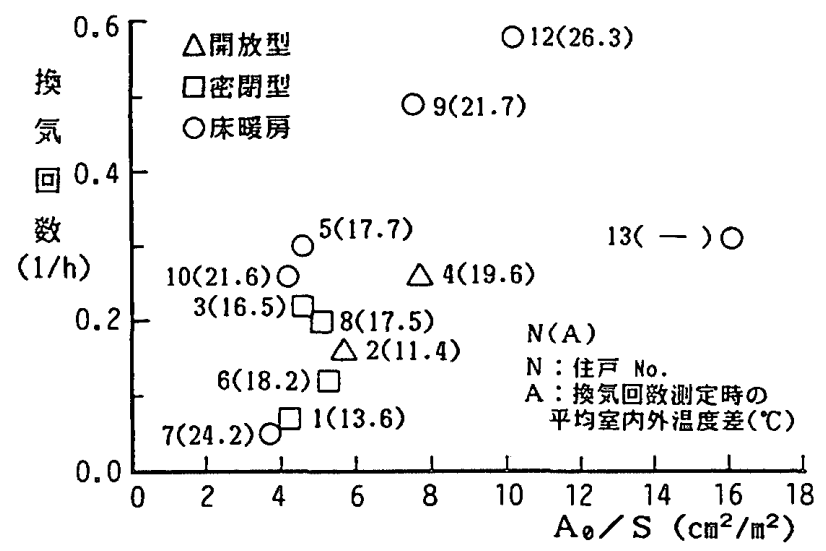

图-17 気密谁能 $\left(A_{0} / S\right)$ と換気回数の関係
裴一5 エネルギ消筫量データの期間とエネルギの主な用途

\begin{tabular}{|c|c|c|c|c|c|}
\hline \multirow[b]{2}{*}{ No } & \multirow{2}{*}{$\begin{array}{c}\widetilde{\tau}-\text { 夕の期間 } \\
(\text { (年間) }\end{array}$} & \multicolumn{3}{|c|}{ 备エネルギの主な用途 } & \multirow[t]{2}{*}{ kcal 換算值 } \\
\hline & & 電気 & ガ ス & 奵油 & \\
\hline$\frac{1}{2}$ & $59.10 \sim 60.9$ & & 炊事.給湯 & 倨房 & $\begin{aligned} & 1 \mathrm{kWh} \\
= & 860 \mathrm{kccl}\end{aligned}$ \\
\hline 3 & $59.10 \sim 60.9$ & * & 暖房. 㰠事。 & 㱏㑥 +シ & \\
\hline 4 & $59.12 \sim 60.11$ & & 炊事.給渴 & & 都市ガス： \\
\hline & $\begin{array}{l}60.3 \sim 61.2 \\
59.11 \sim 60.10\end{array}$ & $\begin{array}{l}\text { 全售䒯 } \\
\text { 照明 }\end{array}$ & 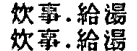 & 暖房 & $\begin{aligned} & 1 \mathrm{~m}^{3} \\
= & 5,000 \mathrm{kcal}\end{aligned}$ \\
\hline 7 & $60.2 \sim 61.1$ & その他 & 婴率 & 㖟屏。給湯 & 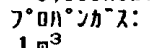 \\
\hline 8 & $59.12 \sim 60.11$ & & 炊筆，給湯 & 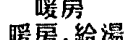 & $\begin{array}{l}1 \mathrm{~m}^{3} \\
=24,000 \mathrm{kcal}\end{array}$ \\
\hline 10 & $59.10 \sim 60.9$ & & 第声 & 暖層。给晹 & $-24,000 \mathrm{NCa}$ \\
\hline 11 & $59.12 \sim 60.11$ & * & 䛈事.緰湯 & 暖房 & 奵油： \\
\hline 12 & 59 & * & ※炊事 & 㖟房.給湯 & \\
\hline 13 & $59.10 \sim 60$. & & ※㰠事 & 暖房。給湯 & $=8,800 \mathrm{kcal}$ \\
\hline
\end{tabular}

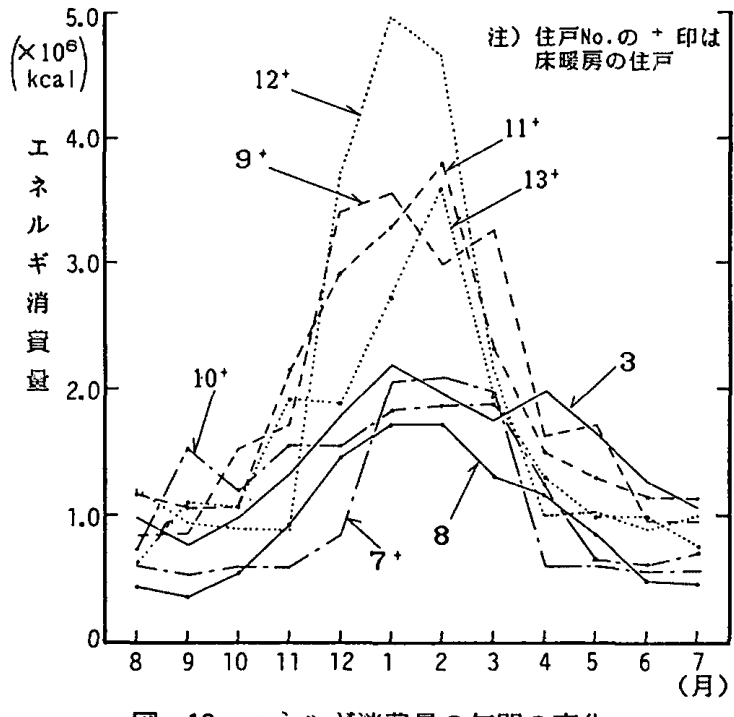

图一18 エネルギ消費量の年間の変化

\section{1 調查方法}

各住戸の電気，ガス，灯油の一年分の使用量を，聞き 込みおよび調睢用紙の郵送などにより調べ，それらを集 計した。各住戸のデータの期間とエネルギの主な用途, および各エネルギの kcal 換算值を表一 5 に示す。デー 夕は，主に家計簿や領収書などの記録に基づくが，No. 1，2，6の灯油の消費量は主婦の記憶による。なお， No. 5 の灯油の消費量は不明であった。No. 3 は密閉型 ガスストーブを使用しているため灯油は使用していな い。床暖房の住戸のうち, No.7, 9, 10,12,13 は給湯 も灯油でまかなっている。

\section{2 エネルギ消費量の年間の変化}

電気，ガス，灯油，すべての月ごとの消費量が分かっ ている住戸 8 戸について，月ごとの合計值の年間の変化 を図一18に示す。どの住戸も 6 月 9 月は変動が小さい と同時に絶対量も小さく, ほぼ $0.5 \sim 1.0 \mathrm{Gcal}$ の間にあ る。11月〜3月は暖房のために消實量は増大するが，ス トーブを使用しているNo.3,8 は比較的緩やかに増加 するのに対し，床暖房の住戸は急激に増加する。消費量 のピークは 1 月〜2月にあり，ストーブ使用の No. 3, 8 および床暖房の No.7, 10 は 1.7 2.2 Gcal の間で相対 


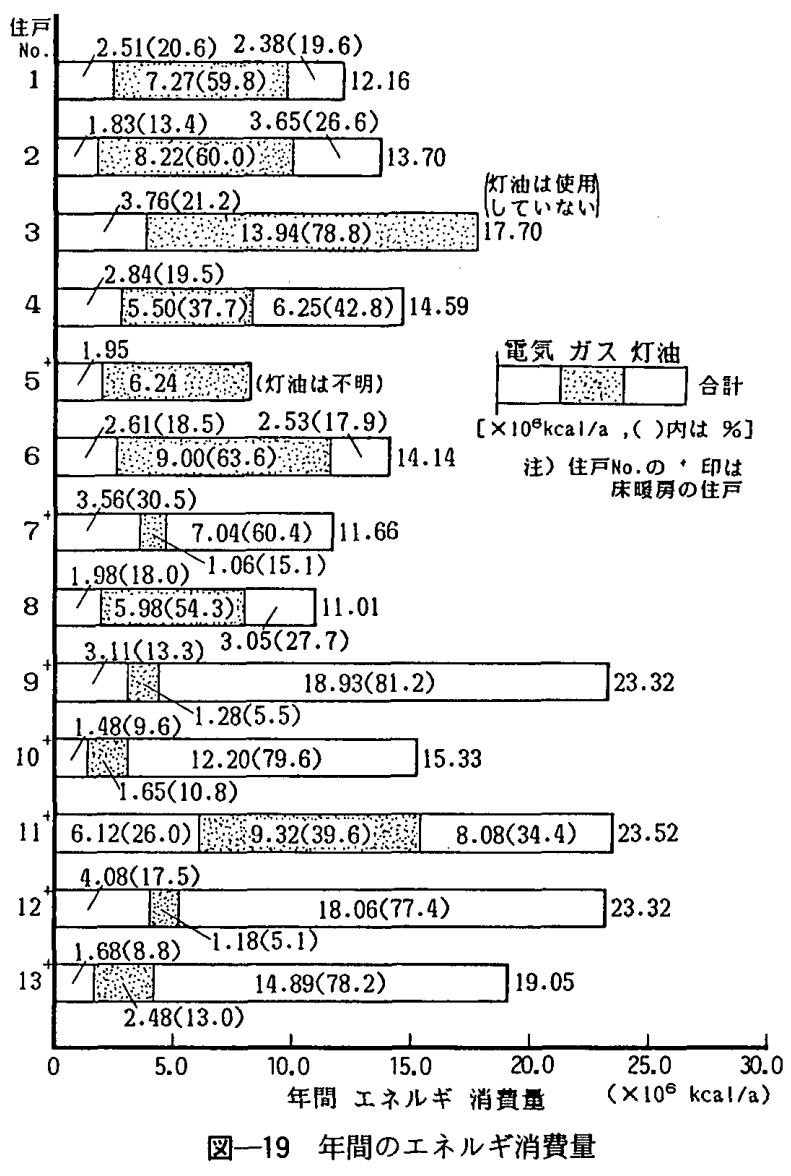

的に少ない。床暖房で居間以外の部屋にもファンコイル を設置してセントラル暖房を行っているNo. 9, 11，12， 13 では $3.0 \mathrm{Gcal}$ 以上になっている。

\section{3 年間のエネルギ消費量}

各住戸の一年間合計の消費量を図一19に示す。各住 戸の電気，ガス，灯油の合計の年間消費量は，11〜24

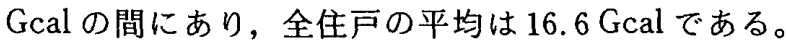
居間で石油ストーブを使用している住戸（No. 1，2，4, $6,8)$ は, $11 \sim 15 \mathrm{Gcal}$ の範囲にあり, 平均は $13.1 \mathrm{Gcal}$ である。ガスストーブ使用の No. 3 は，石油ストーブ使 用の住戸に比べてやや多い。床暖房の住戸 (No.7，9， $10,11,12,13)$ は $11 \sim 24 \mathrm{Gcal}$ の間でばらついている が，6戸の平均は $19.4 \mathrm{Gcal} に な り ，$ 石油ストーブの住 戸に比べて約 $6 \mathrm{Gcal}$ 多くなっている。

No. 7 は断熱気密性能が高く, 暖房時間も朝 2 時間だ けで済んでいるが，年間のエネルギ消費量はNo. 9, 11， 12 の約半分でストーブ使用の住戸と同レベルである。 No. 9, 11, 12,13 のセントラル暖房の住戸は他と比べて 年間消費量が非常に大きく 19 - 24 Gcal である。気密性 能が低いことも一因であると推定される。

次に，灯油を暖房のみに使用している住戸 (No.1， $2,4,6,8,11)$ の年間灯油消費量を見ると，2.3 8.1 Gcal の間にあり平均は $4.3 \mathrm{Gcal}$ になる。床暖房の No. 11 が最も大きく，その他のストーブ使用の住戸では, 居間で石油ストーブ 2 台を使用しているNo. 4 の消費量
が最も多くなっていた。

7. まとめ

（1）気密性能

今回測定した住宅の気密性能は, 2 戸を除きグレード 4 以上であった。

（2）温熱環境

床暖房の住宅では，コンクリートスラブの蓄熱効果も あって一日の温度変化は小さい。また, 上下の温度差は 極めて小さく,グローブ温度は乾球温度よりも団らん時 の最大で $1^{\circ} \mathrm{C}$ 高い。

ストーブ暖房の住宅では, 前回の公社分譲住宅の実測 例 ${ }^{10)}$ と傾向は似ているが, 全般に上下温度差, 室間の温 度差等で示される温熱環境は向上している。

\section{(3) 空気環境}

開放型ストーブを使用する住戸では， $\mathrm{CO}_{2}$ と $\mathrm{NO}_{2}$ 濃 度の両方が高く, 開放型ストーブ使用の No.2 では $\mathrm{CO}_{2}$ 濃度が $5000 \mathrm{ppm}$ を越えた。また両方の濃度の間には正 の相関が見られた。

$A_{0} / S$ が $6 \mathrm{~cm}^{2} / \mathrm{m}^{2}$ 以下になると, $\mathrm{CO}_{2}, \mathrm{NO}_{2}$ の濃度の 高い住戸が増加し, 日平均 $\mathrm{CO}_{2}$ 濃度では 8 例中 6 例が $1000 \mathrm{ppm}$ を越えた。

（4）エネルギ消費量

石油ストーブ使用住戸の年間エネルギ消費量は11 $15 \mathrm{Gcal}$ ，床暖房の住戸は11 24 Gcal であった。

断熱気密性能が高く温熱環境の良好な No. 7 の住戸 は，床暖房であるが年間エネルギ消費量はストーブ使用 の住戸と同程度であった。

\section{謝 辞}

調查を実施するに当たっては，三菱地所(株)仙台支店, 秋田工業(株)仙台支店，ならびに(株)北洲ハウジング仙 台支店より便宜を計って頂きました。また，国立公衆衛 生院技官 小峯裕己氏，三井建設(株)技術研究所 大山信 一氏には種々の面でご協力頂きました。さらに，調查対 象住戸の居住者の方々には,多大なご協力を頂きました。 御世話になった方々に，心から謝意を表します。

注

1）気密性能グレードは， $A_{0} / S$ の測定值が 1 6段階の間で 適度にばらつき，また各国の水準や，戸建住宅，集合住 宅の差なゼがグレードの各段階に対応するように，工業 標準数を基にして設定されているグ。

2）各時刻ごとに，居間で暖房しているか否かを判定し，暖 房している日数を調查期間日数に対する割合で表したも の。

3）バッジは，武薬（トリエタノールアミン）を含浸させた 万紙からなっており，一定期間空気中に暴露する。回収 された後, 発色液を加えて，吸光分析計により吸光度を 測定し，測定期間内の $\mathrm{NO}_{2}$ 濃度を算出する。詳細は文献 11)を参照のこと。

本論文に関連する既発表論文 
1）牧田一志, 長谷川房雄, 吉野 博, 赤林伸一：仙台市の 断熱気密性能の高い戸建住宅における熱・空気環境の実 測調查 その 1 調㚗概要と温熱環境の調奋結果：日本 建築学会大会学術講演梗概集, 昭和 60 年 10 月

2）大山信一, 長谷川房雄, 吉野 博, 内海康雄, 赤榆伸一, 牧田一志：仙台市の断熱気密性能の高い戸建住宅におけ る熱・空気環境の実測調查 その 2 気密性能及び湿度 の測定結果：日本建築学会大会学術講演梗概篹, 昭和 60 年 10 月

3）内海康雄, 長谷川房雄, 吉野 博, 松本 博, 赤妳伸一, 小㿾裕己：仙台市の断熱気密性能の高い戸建住宅におけ る熱・空気環境の実測調査 その 3 室内空気㻴境の調 亘報告：日本建築学会大会学術講演梗概集, 昭和 60 年 10 月

\section{参考文献}

4）長谷川房雄, 吉野 博, 赤林伸一：東北地方都市部の木 造独立住宅における冬期の温熱㻴境に関する調查研究： 日本建築学会論文報告集, 第 326 号, 昭和 58 年 4 月

5）長谷川房雄, 吉野 博, 新井宏朋, 岩崎 惯, 赤林伸一, 菊田道宣：脑卒中の発症と住䍗境との関係についての山 形県郡部を対象とした調首研究：日本公衆衛生雑誌, 第 32 巻第 4 号, 昭和 60 年 4 月
6）牧田一志, 長谷川房雄, 吉野 博, 赤林伸一, 菊田道宣 : 東北地方の住宅における温熱環境謂查 その 18 岩手 県郡部（沢内村）の木造住宅を対象とした冬季の室温に 関する調查結果, および既往の調查結果との比較：日本 建築学会東北支部研究報告集, 第 46 号, 昭和 60 年 11 月

7）村上周三, 吉野 博：住宅の気密性能に関する調查研究 :日本建築学会論文報告集, 第 325 号, 昭和 58 年 3 月

8）佐々木 隆, 木造在来構法の改良に関する研究委員会： 北海道における各種楎法住宅の気密性能の胃状について, 䆩地住宅としての木造在来構法の改良に関する研究 そ の 4: 日本建築学会北海道支部, 昭和 59 年 3 月

9）吉野 博, 長谷川房雄, 内海康雄: 在来楧法の木造戸建 て住宅における気密性能の実测結果と既往データとの比 筑学会東北支部研究報告集, 昭和 56 年 11 月

10）長谷川房雄, 吉野 博, 赤林伸一：東北地方の住宅にお ける温熱環境調查 その 4 仙台市と酒田市の木造独立 住宅における冬期の温湿度について：日本建築学会東北 支部研究報告集, 昭和 55 年 1 月

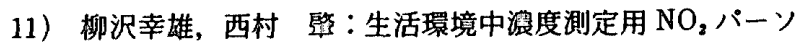
ナルサンプラー：大気污染学会誌, 第 15 巻第 8 号, 1980 


\title{
SYNOPSIS
}

UDC : 697.11:697.003.1:728.011

\section{INVESTIGATION OF INDOOR THERMAL ENVIRONMENT, AIR QUALITY AND ENERGY CONSUMPTION IN DETACHED HOUSES OF WOOD-FRAME CONSTRUCTION IN SENDAI CITY}

\author{
by Dr. HIROSHI YOSHINO, Associate Prof. of Tohoku \\ Univ, , Dr. FUSAO hasegaWA, Prof. of Tohoku Insti- \\ tute of Technology, Dr. HIROSHI MATSUMOTO, Re- \\ search Associate of Tohoku Univ., Dr. YASUO UTSUMI, \\ Research Associate of Miyagi National College of Tech- \\ nology, Dr. SHIN-ICHI AKABAYASHI, Research Associ- \\ ate of University of Tokyo, and KAZUSHI MAKITA, \\ Sekisui Chemical Co., Ltd. Members of A. I. J.
}

The air-tightness, indoor thermal environment, air quality and energy consumption in 13 units of highly insulated detached houses of wood-frame construction in and around Sendai city were investigated during winter of 1985. The results of this investigation are as follows:

(1) Air-tightness

The equivalent leakage area per unit floor area of investigated houses except for 2 houses was less than 8 $\mathrm{cm}^{2} / \mathrm{m}^{2}$.

(2) Indoor thermal environment

In the houses with a floor heating system, the room temperature was stable due to the heat storage effect of floor concrete slab, the vertical temperature gradient in the living room was small, and the globe temperature in the living room during the heating time after supper was $1.0^{\circ} \mathrm{C}$ higher at the maximum than air temperature.

In the houses with an oil heater, the air temperature at the point of $110 \mathrm{~cm}$ above the floor level in the living room was about $20^{\circ} \mathrm{C}$ during the heating time after supper and was about $10^{\circ} \mathrm{C}$ in the early morning. The vertical temperature difference between the points of $110 \mathrm{~cm}$ and $5 \mathrm{~cm}$ above the floor level in the living room was 4 to $8^{\circ} \mathrm{C}$ during the heating time after the supper. The ratio of the temperature difference between the heated living room and the other unheated rooms to the indoor and outdoor temperature difference was scattered in the range of 0.4 to 0.8 .

( 3 ) Indoor air quality

The concentrations of $\mathrm{CO}_{2}$ and $\mathrm{NO}_{2}$ in indoor air of houses with unvented oil heater were high. In the houses with high $\mathrm{CO}_{2}$ concentration, the concentration of $\mathrm{NO}_{2}$ was also high. In some houses, the equivalent leakage area per unit floor area of which was less than $6 \mathrm{~cm}^{2} / \mathrm{m}^{2}$, the concentrations of $\mathrm{CO}_{2}$ and $\mathrm{NO}_{2}$ were so high.

\section{(4) Energy consumption}

The quantity of energy consumption for all uses in the houses with an oil heater was 11 to 15 Gcal per year and that in the houses with a floor heating system was 11 to $24 \mathrm{Gcal}$ per year. 